\title{
Role of awns in ear water-use efficiency and grain weight in barley
}

\author{
J Bort*, A Febrero, T Amaro, JL Araus \\ Unitat de Fisiologia Vegetal, Facultat de Biologia, Universitat de Barcelona, Avda Diagonal, 645, \\ E08028 Barcelona, Spain
}

(Received 7 July 1993; accepted 13 December 1993)

\begin{abstract}
Summary - Two near-isogenic 6-rowed barley genotypes (Hordeum vulgare L cv Atlas), with and without awns, were grown in pots under Mediterranean conditions. The plants were watered daily. For each genotype, total net photosynthesis and water-use efficiency (WUE: net photosynthesis/transpiration) of ears and flag leaves were measured 3 times during grain filling: 1,3 and 4 weeks after anthesis. The total photosynthesis of awned ears was markedly higher than that of awnless ears, until 3 weeks after anthesis. Thereafter, photosynthetic rates decreased faster in awned than in awnless ears. The WUE of awned ears was always higher than that of awnless ears. In fact, the WUE of awns alone was 2 to 3 times higher than the WUE of awnless ears during grain filling. The mature kernel dry weight was higher in the awned genotype than in the awnless genotype. Carbon isotope discrimination of kernels in the awned genotype was lower than in the awnless genotype. Thus, the presence of awns seem to help the ears to maintain higher rates of photosynthesis and WUE throughout the grain-filling period, and may be related to the greater kernel dry weight in the awned genotype, even under well-irrigated conditions. In an experiment in which either the ears or the flag leaves were darkened, the importance of the role of the ear was demonstrated, especially in the awned genotype, in supplying assimilates to the grain. When the ear was darkened, total grain yield per ear was reduced by $37.4 \%$ in the awned genotype, but by only $14.8 \%$ in the awnless genotype. Darkening the flag leaf increased carbon isotope discrimination in the mature kernels of the 2 genotypes, with respect to undarkened plants, especially in the awnless genotype. The alteration of the source-sink relationship in the plant may be responsible for this response to carbon isotope discrimination.
\end{abstract}

barley / awn / water-use efficiency/photosynthesis / yield

Résumé - Rôle des barbes dans l'efficience d'utilisation de l'eau et le poids de grain chez l'orge. Deux variétés isogéniques (avec et sans barbes) d'orge à 6 rangs (Hordeum vulgare $L$ cV Altas), ont grandi dans des pots sous conditions méditerranéennes. Les plantes ont été arrosées chaque jour. Pour chaque génotype, on a mesuré la photosynthèse nette totale et l'efficience d'utilisation de l'eau (WUE = photosynthèse nette/transpiration) des épis et des feuilles étendards 3 fois au long du remplissage du grain: 1, 3 et 4 sem après l'anthèse. La photosynthèse totale des génotypes avec barbes a été supérieure à celle des génotypes sans barbes, jusqu'à 3 sem après l'anthèse. Par la suite, les valeurs de la photosynthèse ont diminué plus rapidement chez les génotypes avec barbes que chez les génotypes sans barbes. La WUE des génotypes avec barbes a toujours été supérieure à celle des "sans barbes". De fait, la WUE chez les épis avec barbes a été 2 ou 3 fois supérieure à celle des épis sans barbes pendant le remplissage du grain. Le poids sec du grain mûr a été supérieur avec le génotype avec barbes par comparaison avec le génotype sans barbes. La discrimination isotopique du carbone des grains chez les génotypes avec barbes a été plus bas que chez les génotypes sans barbes. Cependant, il semble que la présence des barbes aide les épis à maintenir élevés les valeurs de la photosynthèse et la WUE pendant la période de remplissage du grain. Cela peut voir un rapport avec l'augmentation du poids sec du grain des génotypes avec barbes, même avec des conditions d'arrosage. Dans une expérience dans laquelle on a soumis à l'obscurité les épis ou les feuilles étendard, on a pu démontrer

\footnotetext{
* Correspondence and reprints
} 
que l'épi a un rôle très important pour fournir des assimilats au grain. Lorsque l'épi a été mis dans l'obscurité, le poids total de grains par épi a été réduit de $37,4 \%$ dans le génotype avec barbes, mais seulement de $14,8 \%$ dans le génotype sans barbes. Lorsque la feuille étendard a été placée dans l'obscurité, la discrimination isotopique du carbone a augmenté dans les grains mûrs, dans les 2 génotypes, par rapport aux plantes non placées dans l'obscurité, spécialement dans le génotype sans barbes. L'altération de la relation source-puits dans les plantes mises dans l'obscurité peut être responsable de cette réponse de la discrimination isotopique du carbone.

orge/barbe/efficience d'utilisation de l'eau/photosynthèse/production

\section{INTRODUCTION}

The physiological role of awns has long been recognized. They take advantage of sunlight, given their high position on the canopy of the crop and the short route of assimilates to the kernels (Blum, 1985).

Evans et al (1972) reported that drought increased the proportion of assimilates contributed by ear photosynthesis to grain filling from 13 to $24 \%$ in awnless ears, and from 34 to $43 \%$ in the awned ears of wheat. However, awns did not increase grain yield in the irrigated treatment, and did not affect the grain number per ear. In fact, Kramer and Didden (1981) demonstrated that awned genotypes of wheat produce higher yields and kernel weights under water shortage, and that when water supply is abundant awns seem to be associated with reduced yield. Teich (1982) reported that, in winter wheat, awned cultivars predominate in warm, dry climates, while awnless cultivars predominate in temperate and more moist areas. Chhabra and Sethi (1989) examined durum wheat genotypes grown under irrigated conditions and reported that flag leaf and awns had more consistent advantage for grain weight than for yield. They concluded that these parameters could not be used as an index of selection for getting higher yielding plants from a mixture of genotypes.

Carbon isotope discrimination $(\Delta)$ has been used as a complementary criterion to assess consistent differences in water-use efficiency (WUE). It has been proposed as an integrated indicator of WUE in $\mathrm{C}_{3}$ cereals (Farquhar and Richards, 1984).

This study was planned to assess the role of awns in the gas-exchange characteristics of barley ears. This cereal crop has received much less attention than wheat. The effect of awns on the supply of assimilates to the growing grains, and thus on yield, was also tested.

\section{MATERIALS AND METHODS}

Two near-isogenic (Stebbins and Yagil, 1966) lines of barley (Hordeum vulgare $L$ ) of the $c V$ Atlas, Inerme (awnless) and Nu-46 (awned), were planted outdoors on February 61990 , at the 'Campos Experimentales', Facultat de Biologia, Universitat de Barcelona, in $40-\mathrm{cm}$ diameter pots containing equal parts of vermiculite and perlite. After germination they were thinned to 6 plants per pot. Plants were watered daily and fertilized with complete Hoagland's solution twice a week. Anthesis occurred during the first week of May.

\section{Gas-exchange experiments}

Gas exchange was measured outdoors with an LCA-3 portable open gas-exchange system (AnaIytical Development Co Ltd, UK) on attached ears and flag leaves (blades and sheaths), 1, 3 and 4 weeks after anthesis. Gas exchange of the central portion of the flag leaf blades was measured with a Parkinson cereal leaf chamber. For the spike, awns, and leaf sheaths, a chamber for needleshaped leaves was used. Measurements were taken between 11.00 am and $1.30 \mathrm{pm}$ (solar time), on plants tagged at anthesis. The chamber was held perpendicular to the solar beam on cloudless days $\left(1500-2000 \mu \mathrm{mol} \mathrm{m}{ }^{-2} \mathrm{~s}^{-1}\right.$ PPFD [photosynthetic photon flux density]). Gas-exchange rates were referenced to 1 side (blade), cylinder (sheath) or prism (spike) area. The leaf temperature during measurements was between 23 and $26^{\circ} \mathrm{C}$, and the relative humidity was between 45 and $60 \%$. Water-use efficiency (WUE) values of awned ears, awnless ears and flag leaves were calculated as the ratio between total photosynthesis rate per organ to total transpiration rate per organ. Assessment of WUE of the awns alone was:

WUE $=\frac{\text { Photosynthesis of awned ears }- \text { Photosynthesis of awnless ears }}{\text { Transpition }}$ Transpiration of awned ears - Transpiration of awnless ears

This formula is only correct if the ears are equivalent in the photosynthetic and transpiring areas in the 2 lines, despite the presence or lack of awns. Comparative data at anthesis and length of flag leaf blade, flag leaf sheath, stem and ear (without awns in the awned genotype) for the 2 genotypes are shown in table I. No differences 
Table I. Length $(\mathrm{cm})$ of flag leaf blade and sheath, stem and ear at anthesis for the awnless and awned genotypes.

\begin{tabular}{lrr}
\hline & $\begin{array}{c}\text { Awnless } \\
\text { genotype }\end{array}$ & $\begin{array}{c}\text { Awned } \\
\text { genotype }\end{array}$ \\
\hline Flag leaf blade & $9.4 \pm 0.8$ & $8.7 \pm 0.8$ \\
Flag leaf sheath & $21.2 \pm 0.4$ & $20.6 \pm 0.3$ \\
Stem & $29.1 \pm 1.7$ & $27.3 \pm 1.5$ \\
Ear & $6.2 \pm 0.2$ & $5.8 \pm 0.3$ \\
\hline
\end{tabular}

$(p<0.05)$ within each parameter were observed between the awned and the awnless genotype. Thus, we can assume rather similar photosynthetic and transpiring areas in ears without awns of the awned genotype, and ears of the awnless genotype, as would be expected for near-isogenic lines differing only in the presence or lack of awns.

\section{Darkening experiments}

Shortly after anthesis (1 week), either the ear or the flag leaf (blade plus sheath) of plants tagged at anthesis was darkened by covering these plant parts with a folded sheet of aluminium, in which a few small holes (about $1-\mathrm{mm}$ diameter) were punched in order to prevent accumulation of gases, as reported earlier (Araus et al, 1993). This covering was maintained until maturity.

\section{Mature kernels}

The ears used for gas-exchange measurements and those from plants used in the darkening experiments were sampled at maturity for kernel yield parameters and analysis of carbon isotope composition in mature kernels.

\section{Carbon isotope analysis}

The kernels from each sampled ear were ground to a fine powder for the ${ }^{13} \mathrm{C} /{ }^{12} \mathrm{C}$ analysis. The ${ }^{13} \mathrm{C} /{ }^{12} \mathrm{C}$ ratios were determined by mass spectrometry by the Isotope Services, Inc, Los Alamos, NM 87544, USA. Values were expressed as $\delta{ }^{13} \mathrm{C}$ values, where

$$
\delta{ }^{13} \mathrm{C}(\%)=\left(R_{\text {sample }} / R_{\text {standard }}-1\right) \times 1000,
$$

where $\mathrm{R}$ is the ${ }^{13} \mathrm{C} /{ }^{12} \mathrm{C}$ ratio. The standard for comparison was a secondary standard calibrated against PeeDee belemnite (PDB) carbonate. The precision of analysis ranged between 0.02 and $0.09 \%$. The value of the discrimination $(\Delta)$ against ${ }^{13} \mathrm{C}$ was obtained from $\delta_{\mathrm{a}}$ and $\delta_{\mathrm{p}}$, where a and $\mathrm{p}$ refer to the air and the plant, respectively (Farquhar et al, 1989):

$$
\Delta=\frac{\delta_{a}-\delta_{p}}{1+\delta_{p}}
$$

On the PDB scale, free atmospheric $\mathrm{CO}_{2}$ has a current deviation, $\delta_{a}$, of $-7.85 \%$.

\section{RESULTS}

\section{Gas-exchange experiments}

On a whole-organ basis, the flag leaves of both awned and awnless plants showed higher rates of transpiration (data not shown) and photosynthesis (fig 1) than awnless ears. The flag leaves of the 2 genotypes also showed similar gas-exchange rates to awned ears. These trends were maintained until 3 weeks after anthesis. After this, the rates of photosynthesis in awned ears decreased faster than in flag leaves or awnless ears. One week after anthesis, awns made up to $85 \%$

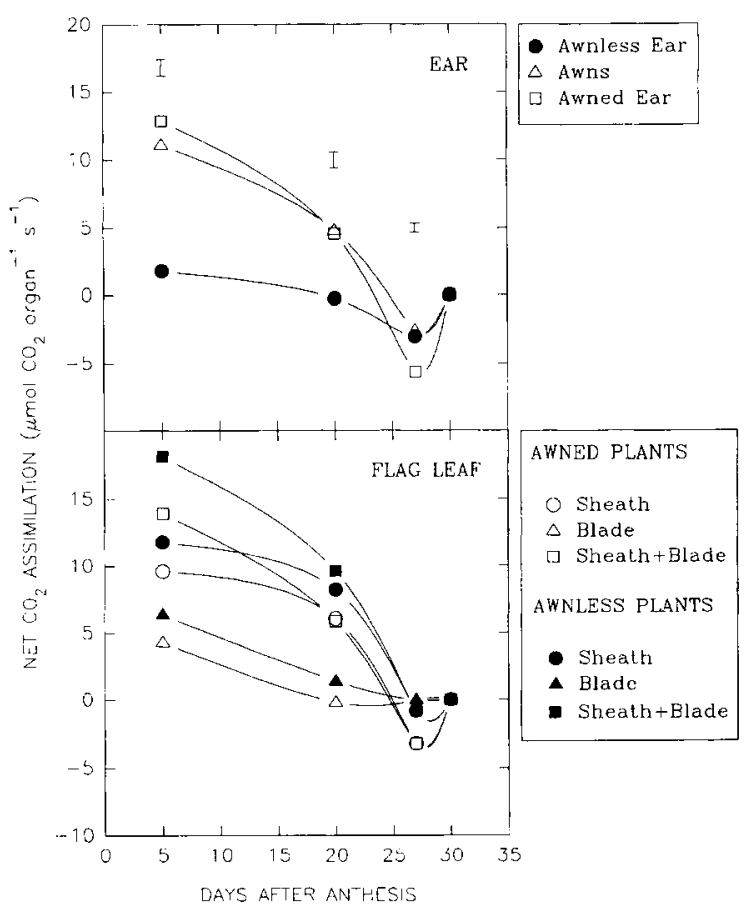

Fig 1. Pattern of net $\mathrm{CO}_{2}$ assimilation throughout grain filling for awned and awnless ears (the rate of awns alone is the difference between them) and flag leaf blade, flag leaf sheath (and calculated whole flag leaf: sheath + blade). Values are averages of $6-10$ replicates. Standard errors of measurements within each sampling date are shown. 
of the net photosynthesis of the ears (calculated as the difference between the total net photosynthesis rates of awned and awnless ears).

The WUE of the flag leaves was similar to that of the awned ears but much higher than that of the awnless ears (fig 2). Early in the grain filling ( 1 week after anthesis) the awned ears showed even higher WUE than the flag leaves. In both the blades and sheaths of the flag leaves, the WUE was similar shortly after anthesis, but these values had strongly decreased in the blades 3 weeks after anthesis. The decrease in the sheath was slower throughout the grain-filling period. In fact, the blades were already senescent around 3 weeks after anthesis. The WUE of awns alone (for explanation see Materials and methods) was 2-3 times higher than the WUE of awnless ears, and similar to or higher than the WUE of flag leaf sheaths, until 3 weeks after anthesis. In addition, the WUE of awns alone maintained positive values (ie net assimilation greater than zero) until more

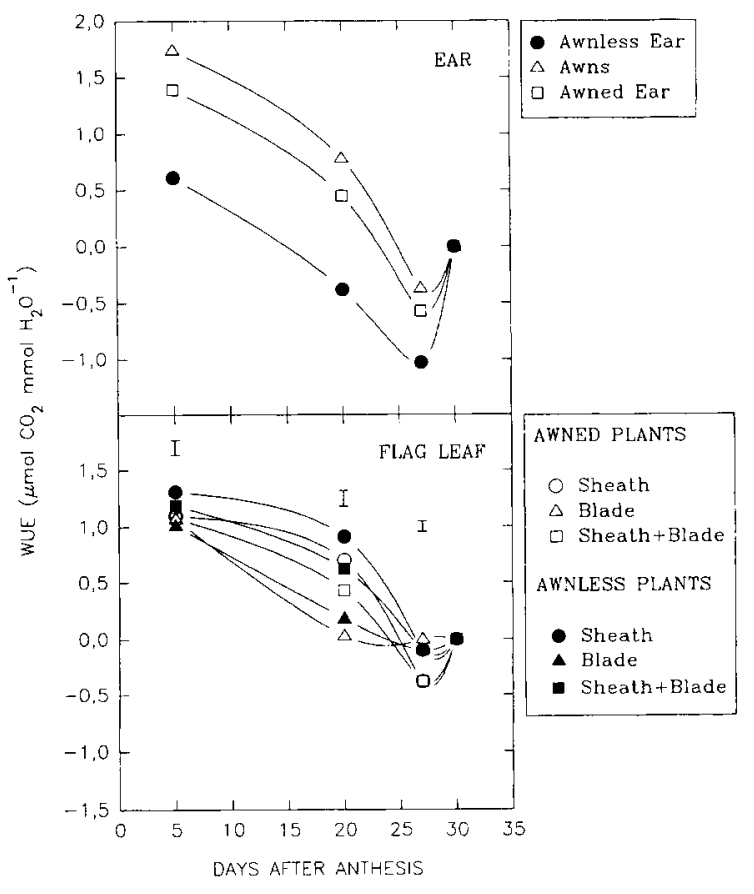

Fig 2. Pattern of water-use efficiency (photosynthesis/transpiration) throughout the grain filling for awned and awnless ears (the rate of awns alone is the difference between them) and flag leaf blade, flag leaf sheath (and calculated whole flag leaf: sheath + blade). Values are averages of 6-10 replicates. Standard errors of measurements within each sampling date are shown. than 3 weeks after anthesis ( $10 \mathrm{~d}$ longer than awnless ears).

The $\Delta$ value of the mature kernel was $0.34 \%$ lower in the awned genotype (fig 3), indicating a higher integrated WUE throughout grain filling.

\section{Yield components}

The total grain yield per ear did not differ significantly between awned and awnless genotypes (fig 4a), but was slightly higher in the awned plants. The kernel dry weight was significantly higher $(p<0.05)$ in the awned genotype than in the awnless genotype (fig $4 \mathrm{~b}$ ). The number of kernels per ear was significantly $(p<0.05)$ lower in the awned genotype (fig 5).

\section{Darkening experiments}

The total grain yield was dramatically lowered by darkening the ear from 1 week after anthesis to maturity, but was not affected by darkening the flag leaf. Darkening of awned

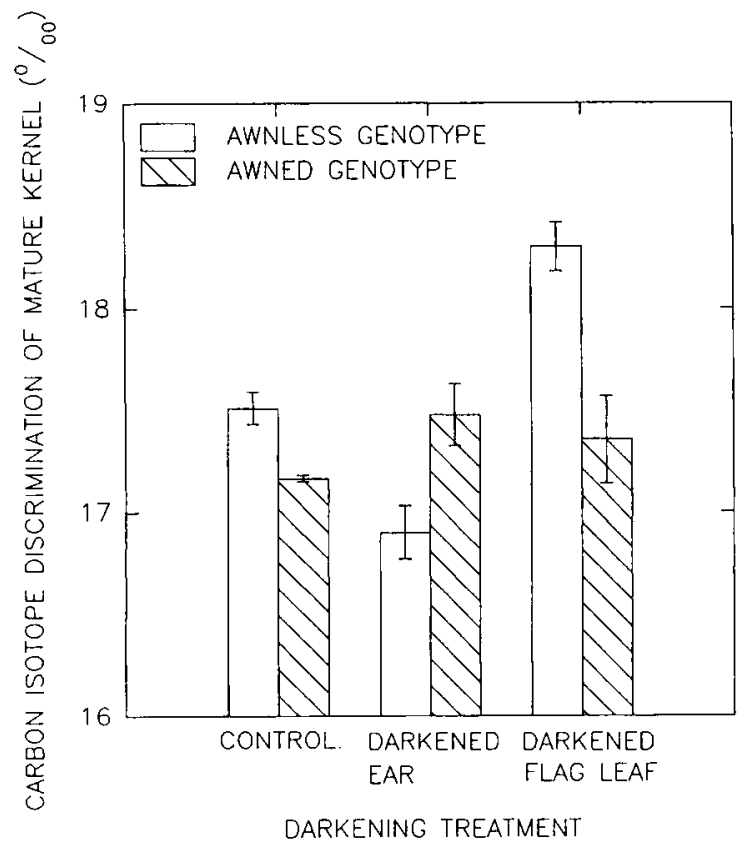

Fig 3. Effect of darkening the flag leaf or the ear on carbon isotope discrimination of mature kernels of awnless genotypes and awned genotypes. Values are averages and standard errors of the mean of $6-10$ replicates. 


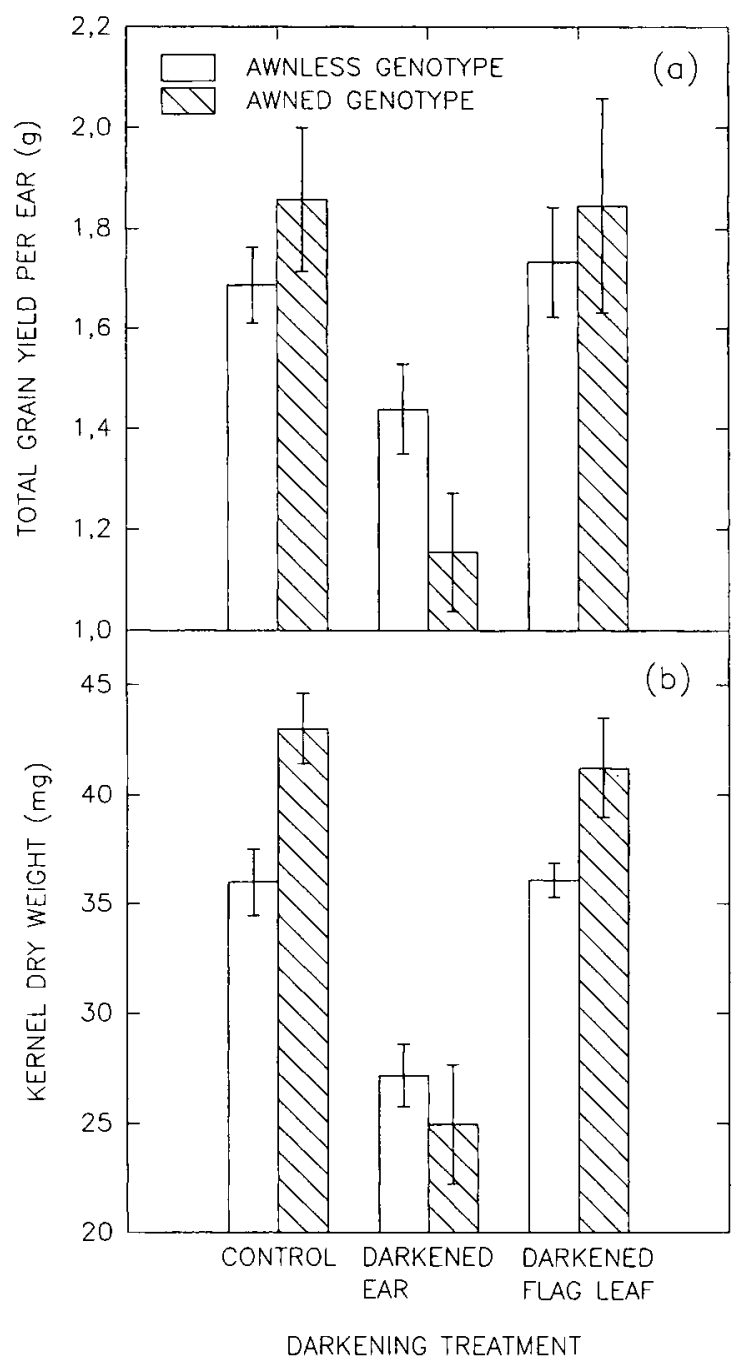

Fig 4. Effect of darkening the flag leaf or the ear on (a) grain yield per ear and (b) kernel dry weight of awnless and awned genotypes. Values are averages and standard errors of the mean of $6-10$ replicates.

ears reduced total grain yield per ear by $37.9 \%$ while darkening of awnless ears reduced yield by only $14.8 \%$ (fig $4 a$ ).

The number of kernels per ear was not modified by darkening the flag leaf, but was increased by darkening the ear (by $12.1 \%$ in the awnless ears and by $9.3 \%$ in the awned ears, fig 5).

The kernel dry weight was significantly reduced by darkening the ear at anthesis. The darkening the flag leaf did not significantly affect the kernel dry weight (fig 4b). The large reduction in total grain yield per ear in the darkened ears in conjunction with the increase in number of kernels per ear produced the combined effect of reducing the kernel dry

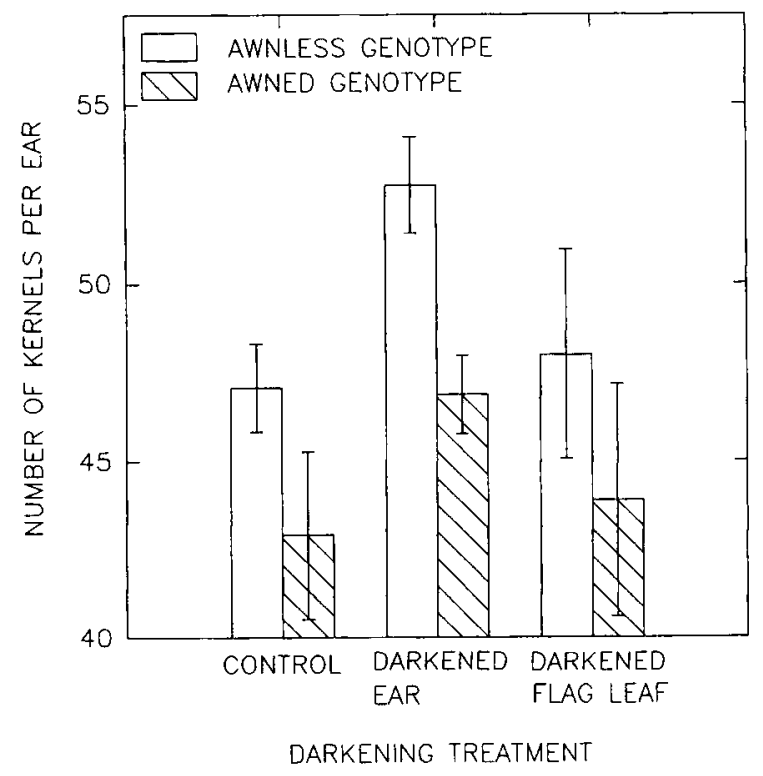

Fig 5. Effect of darkening the flag leaf or the ear on number of kernels per ear of awnless and awned genotypes. Values are averages and standard errors of the mean of $6-10$ replicates.

weight by $24.5 \%$ in the awnless genotype, and by $42.0 \%$ in the awned genotype.

Darkening the flag leaf increased the difference between awnless and awned genotyes in $\Delta$ of mature kernels, from $0.34 \%$ (non-darkened plants) to $0.95 \%$ (fig 3 ). On the other hand, darkening the ear promoted a $0.57 \%$ higher $\Delta$ value in the kernels of the awned genotype with respect to the awnless genotype.

\section{DISCUSSION}

Our results on gas-exchange measurements and $\Delta$ suggest that awns help the ears to maintain a higher WUE throughout the grainfilling period, in addition to the supply of assimilates to the grain (see below). In wheat, the presence of awns can double the rate of net ear photosynthesis (Apel, 1966; Evans and Rawson, 1970), which agrees with the fact that rather more than half the total number of stomata of awned wheat spikelets, and $75 \%$ of stomata of barley spikelets, were in the awns (Perlitius, 1903). A more recent work by Teare et al (1972) found about $20 \%$ of stomata of the wheat spikelets in the awns, but also reported a wide range of variation among 19 cultivars. In addition, awns develop later than flag leaves and may have a lower 
tendency to senescence during grain filling (Evans et al, 1972). However, after awns have undergone senescence (ie become photosynthetically inactive) they could take on a protective role in the ear, shading the excess solar radiation and thus softening the water vapor pressure gradient between the air and the bracts. At this point in grain filling, the bracts remain photosynthetically active. The low WUE of the bracts may result from respiratory processes occurring in filling kernels, that decrease net photosynthesis (Araus et al, 1993).

Our results show that the presence of awns also improved kernel dry weight even under well-irrigated conditions (fig 4b).

The results of the darkening experiment suggest that assimilates in the grains come basically from the ear. Furthermore, the greater reduction of total grain yield, after darkening the ear in the awned genotype $(37.9 \%)$, compared to the awnless genotype $(14.8 \%)$ reflects the important role of the awns in supplying assimilates to the grain. Interestingly, the number of kernels per ear was significantly higher in the spike with lower photosynthetic capacity (ie in the awnless ears). The presence of awns seems to have a negative effect on the proper setting of viable florets at the primary developmental stages of the spike. As suggested by Binham (1969), awns may compete during development with the later florets and thereby reduce grain number per ear. Teich (1982) also proposed that, in winter wheat, awns influence the yield by a mechanism acting before fertilization, when seed number is determined, and that there is an interaction between awns and environment in the determination of yield during grain filling.

It is unclear why darkening the ear apparently reduced the abortion of some florets in the ears, and thereby increased the number of kernels per spike, in both genotypes. Darkening began 1 week after anthesis, when all floret parts had already been set. The number of kernels per ear may be reduced by rapid development of grains from the first florets to reach anthesis (Rawson and Evans, 1970). Therefore, in our experimental conditions, the lower availability of assimilates, because of darkening, might have enabled growth of more grains, including those that set later.

In the awnless genotype, the kernels of the undarkened ears showed $0.61 \%$ higher $\Delta$ than in the darkened ears, which can be explained by the absence of refixation of $\mathrm{CO}_{2}$ in the darkened ears. Thus, no further discrimination against ${ }^{13} \mathrm{C}$ can occur in the carbon evolved as $\mathrm{CO}_{2}$ by respiration of the developing kernels (Araus et al, 1993). On the other hand, the undarkened awned ears showed $0.31 \%$ lower $\Delta$ in the mature kernels than the darkened awned ears, which might be an effect of the higher $\mathrm{CO}_{2}$ loss by respiration from the awns. This might increase the demand for assimilates from the flag leaves, more in the awned than in the awnless genotype. This would result in an increase of the $\Delta$ value (photosynthates coming from the flag leaf; Bort et al, 1991) in the mature kernels of the awned genotype, compared to the awnless genotype.

Finally, darkening the flag leaf may have forced the ear to compensate for the absent source of photosynthesis by maintaining a higher gas-exchange rate, ie higher stomatal conductance, thus lower WUE and greater $\Delta$. This effect being more evident in awnless ears.

\section{CONCLUSIONS}

Our results suggest that awns improve net $\mathrm{CO}_{2}$ fixation and WUE of barley ears throughout the grain filling. The increase in WUE due to awns is a consequence of their relatively higher assimilation than transpiration, on a per-organ basis.

The presence of awns in barley significantly increases the kernel dry weight, and thus grain quality, under well-irrigated conditions but only slightly increases the grain yield per ear.

Based on our darkening experiment, the photosynthetic assimilation by the ear, from 1 week after anthesis to maturity, accounts for about $40 \%$ of total grain yield, in the awned genotype, but for only about $15 \%$ in the awnless genotype.

\section{ACKNOWLEDGMENTS}

We wish to thank Dr Chery, from ENSA, Montpellier, France, for supplying seeds. We are grateful to R Rycroft for correcting the English manuscript, and to $\mathrm{K}$ Hogan for his comments on the manu- 
script. This work has been partially supported by the research grant AGF92-0301 from the CICYT, Spain.

\section{REFERENCES}

Araus JL, Brown RH, Febrero A, Bort J, Serret MD (1993) Ear photosynthesis, carbon isotope discrimination and the contribution of respiratory $\mathrm{CO}_{2}$ to differences in grain mass in durum wheat. Plant Cell Environ 16, 383-392

Apel P (1966) Die Bedeutung der Granen für die Kornentwicklung, III. Photosynthese intensität der Ähren verschiedener Gerten-und Weizensorten. Kulturpflanze 14, 163-169

Bingham J (1969) The physiological determinants of grain yield in cereals. Agric Prog 44, 30-42

Blum A (1985) Photosynthesis and transpiration in leaves and ears of wheat and barley varieties. $J$ Exp Bot 36, 432-440

Bort J, Febrero A, Alegre L, Araus JL (1991) Role of $\mathrm{CO}_{2}$ refixation by the barley ear on grain filling. In: Int Symp Physiol Determination Crop Yield. University of Florida, Gainesville, FI

Chhabra AK, Sethi SK (1989) Contribution and association of awns and flag-leaf with yield and its components in durum wheat. Cereal Res Commun 17, 265-271

Evans LT, Rawson HM (1970) Photosynthesis and respiration by the flag leaf and components of the ear during grain development in wheat. Aust J Biol Sci 23, 245-254
Evans LT, Bingham J, Jackson P, Sutherland J (1972) Effect of awns and drought on the supply of photosynthate and its distribution within wheat ears. Ann Appl Biol 70, 67-76

Farquhar GD, Ehleringer JR, Hubick KT (1989) Carbon isotope discrimination and photosynthesis. Annu Rev Plant Physiol Plant Mol Biol $40,503-37$

Farquhar GD, Richards RA (1984) Isotopic composition of plant carbon correlates with wateruse efficiency of wheat genotypes. Aust $J$ Plant Physiol 11, 539-552

Kramer T, Didden FAM (1981) The influence of awns on grain yield and kernel weight in spring wheat (Triticum aestivum L). Cereal Res Commun $9,25-30$

Perlitius L (1903) Der Einfluss der Begrannung auf die Wasserverdunstung der Ähren und die Kornqualität. Inaug Diss Univ Breslau pp 77

Rawson HM, Evans LT (1970) The pattern of grain growth within the ear of wheat. Aust $J$ Biol Sci 23, 753-64

Stebbins GL, Yagil E (1966) The morphogenetic effects of the hooded gene in barley. I. The course of development in hooded and awned genotypes. Genetics 54, 727-741

Teare ID, Law AG, Simmons GF (1972) Stomatal frequency and distribution on the inflorescence of Triticum aestivum. Can J Plant Sci 52 (1), 89-94

Teich $\mathrm{AH}$ (1982) Interaction of awns and environment on grain yield in winter wheat (Triticum aestivum L). Cereal Res Commun 10, 11-15 